\title{
You Better Work: Employment Discrimination, Title VII, and Sexual Orientation
}

\author{
Bridget Brazil*
}

\section{INTRODUCTION}

What do Tim Cook, CEO of Apple, Sally Susman, Executive Vice President of Corporate Affairs at Pfizer, and Alex Schultz, Vice President of Growth at Facebook, all have in common? In many states, each of these important American business leaders could lose their job simply because of their sexual orientation. ${ }^{1}$ These leaders are but three of the innumerable examples of LGBTQ employees and their contributions to American businesses and society in general. Yet, for these businesspeople, and LGBTQ employees all over the United States, a simple move across state lines could mean the loss of Title VII protection. This inequality is due to the differing interpretations of Title VII of the Civil Rights Act of 1964 by the circuit courts. ${ }^{2}$ A gay man employed in Indiana cannot be fired because he is married to a man. But, if that same man began working in Florida, he could be fired based

\footnotetext{
* J.D. candidate 2019, University of Kansas School of Law; B.A. 2016, Tufts University. I would like to thank the staff and editorial board of the University of Kansas Law Review, especially Nancy Musick and Paul Keithley, for their time and effort in helping edit this piece. I would also like to give a special thank you to my friends and family, especially Jessie Pringle, Kyle Klucas, and Clifford Brazen, for their input and support throughout the writing process and all of law school.

1. James Cook, Apple CEO Tim Cook Has Explained in a Heartfelt Speech Why he Came Out as Gay, BUSINESS INSIDER (Oct. 5, 2015, 4:29 AM), http://www.businessinsider.com/apple-ceotim-cook-gay-human-rights-campaign-speech-2015-10 [https://perma.cc/EUG5-W7L9]; Jillian D'onfro \& Tess Danielson, Power Players: The Most Important Facebook Execs You've Never Heard of, BUSINESS INSIDER (Nov. 11, 2015, 4:30 PM), https://www.businessinsider.com/the-mostimportant-facebook-execs-youve-never-heard-of-2015-9/\#alex-schultz-is-behind-facebooksstaggering-user-stats-6 [https://perma.cc/5ZKC-7TVJ]; Stephanie Sandberg, The New Supermodels - How Out LBT+ Women in Business Drive Impact, HufFingTON Post (Apr. 28, 2017, 5:50 PM, updated Jan. 16, 2018), https://www.huffingtonpost.com/entry/the-new-supermodels-how-out-lbtwomen-in-business_us_58 fe5eb2e4b0f420ad99cad2 [https://perma.cc/Z3SJ-JKUX].

2. Compare Hively v. Ivy Tech Cmty. Coll. of Ind., 853 F.3d 339, 345-49 (7th Cir. 2017) (en banc) (holding discrimination based on sexual orientation violates Title VII), with Evans v. Ga. Reg'l Hosp., 850 F.3d 1248, 1255-57 (11th Cir. 2017) (holding Title VII does not protect sexual orientation discrimination), cert. denied, 138 S. Ct. 557 (2017).
} 
on his sexuality despite the fact that Title VII is the law of the land in both states. ${ }^{3}$ LGBTQ individuals should be just as free to live and work in any of the fifty states as straight individuals.

Since 1964, the Civil Rights Act has protected Americans from discrimination in a wide range of areas. Specifically, Title VII of the Act protects against discrimination by employers based on a range of immutable characteristics, including race and sex. ${ }^{4}$ However, as traditional notions of sex and gender change, courts have failed to interpret the prohibition on sex discrimination contained in Title VII consistently. ${ }^{5}$ In April 2017, the Seventh Circuit Court of Appeals in Hively v. Ivy Tech Community College of Indiana, sitting en banc, overruled an earlier decision of a three-judge panel and held that Title VII's prohibition on sex discrimination protects employees from discrimination based on sexual orientation. ${ }^{6}$ This decision created a circuit split over whether the prohibition on sex discrimination extends to discrimination based on sexual orientation. ${ }^{7}$

Title VII makes it unlawful:

(1) to fail or refuse to hire or to discharge any individual, or otherwise to discriminate against any individual with respect to his compensation, terms, conditions, or privileges of employment, because of such individual's race, color, religion, sex, or national origin; or

(2) to limit, segregate, or classify his employees or applicants for employment in any way which would deprive or tend to deprive any individual of employment opportunities or otherwise adversely affect his status as an employee, because of such individual's race, color, religion, sex, or national origin. ${ }^{8}$

While some courts, like the Seventh Circuit in Hively and the Second Circuit in Zarda v. Altitude Express, Inc., hold that this language prohibits discrimination based on sexual orientation, ${ }^{9}$ others, like the Eleventh Circuit in Evans v. Georgia Regional Hospital, hold that the Act only prohibits discrimination based on sex only in the narrowest

3. See cases cited supra note 2 .

4. 42 U.S.C. $\$ 2000 \mathrm{e}-2$ (a) (2012).

5. Compare Hively, 853 F.3d at 345-49, with Evans, 850 F.3d at 1255-57.

6. Hively, 853 F.3d at 341.

7. Compare id. (Title VII protects employees from sexual orientation discrimination), with Evans, 850 F.3d at 1255 (finding Title VII does not cover sexual orientation discrimination), and Christiansen v. Omnicom Grp., Inc., 852 F.3d 195, 199 (2d Cir. 2017) (per curiam) (same), abrogated by Zarda v. Altitude Express, Inc., 883 F.3d 100 (2d Cir. 2018) (en banc).

8. 42 U.S.C. $\S 2000 \mathrm{e}-2$ (a).

9. Hively, 853 F.3d at 341 ; Zarda, 883 F.3d at 108. 
sense. ${ }^{10}$ These courts reason that the legislature never intended for Title VII to apply to discrimination based on sexual orientation and that the plain meaning of the text does not imply any level of protection for lesbian, gay, or bisexual employees. ${ }^{11}$ This view is fundamentally flawed not only from a policy and human rights standpoint, but also from a statutory interpretation standpoint. ${ }^{12}$ The Second and Seventh Circuits' interpretation of Title VII fulfills the goals of the Civil Rights Act of 1964 more adequately and not only fits with the plain meaning of the statute, but also with the previous interpretations of Title VII by the Supreme Court. For these reasons, the Supreme Court should adopt this interpretation.

Part II of this Comment lays out the important terminology and definitions that are used throughout its discussion of Title VII. Part III explores the background of Title VII's prohibition on sex discrimination in general and the background of the circuit split. Part IV explores multiple theories of statutory construction, which indicate that Title VII should, in fact, protect against discrimination based on sexual orientation. Lastly, Part V offers a brief conclusion of the arguments presented in this Comment.

\section{On TERminology: SEX, Gender AND Title VII}

Today, many people agree that "gender" and "sex" do not share a common definition. Merriam-Webster defines sex as "either of the two major forms of individuals that occur in many species and that are distinguished respectively as female or male especially on the basis of their reproductive organs and structures," 13 and defines gender as "the behavioral, cultural, or psychological traits typically associated with one

\footnotetext{
10. $850 \mathrm{~F} .3 \mathrm{~d}$ at $1255-57$.

11. Id. at 1255-56 (citing Blum v. Gulf Oil Corp., 597 F.2d 936 (5th Cir. 1979) (per curiam)) (stating only the conclusion that Title VII does not prohibit sexual orientation-based discrimination and relying on the statement made in Smith v. Liberty Mut. Ins. Co., 569 F.2d 325, 327 (5th Cir. 1978), that "Congress by its proscription of sex discrimination intended only to guarantee equal job opportunities for males and females"); Omnicom Grp., Inc., 852 F.3d at 199 (citing Simonton v. Runyon, 232 F.3d 33, 35 (2d Cir. 2000)). In Simonton, the court noted that "[a]lthough congressional inaction subsequent to the enactment of a statute is not always a helpful guide, Congress's refusal to expand the reach of Title VII is strong evidence of congressional intent in the face of consistent judicial decisions refusing to interpret 'sex' to include sexual orientation." 232 F.3d at 35 .

12. Infra Sections IV.B.1, 5 .

13. Sex, MERRIAM-WEBSTER, https://www.merriam-webster.com/dictionary/sex [https://per ma.cc/8Z5F-E8KC] (last visited Jan. 27, 2019).
} 
sex." ${ }^{14}$ In other words, sex refers to a person's biological characteristics while gender refers to the traits society stereotypically associates with those biological characteristics. ${ }^{15}$ Title VII refers only to discrimination based on "sex," but the Supreme Court has already interpreted this to encompass discrimination based on gender - that is, the extent to which one conforms with the traits stereotypically associated with their gender. ${ }^{16}$ Thus, in discussing Title VII and its application, courts often use the terms "sex" and "gender" interchangeably not because these courts feel that one's gender is necessarily the same as one's sex, but rather because, as used in Title VII, the term "sex" encompasses both the biological sex of a person as well as the gender identity of that individual. ${ }^{17}$ This Comment adopts the same approach in discussing Title VII. When the discussion is outside of the scope of Title VII, this Comment uses "sex" and "gender" as defined in this Comment.

Additionally, while the content of this Comment certainly relates to the LGBTQ community as a whole, it addresses only the claims of lesbian, gay, and bisexual individuals. ${ }^{18}$ This Comment is not intended to address the related and important, but separate, jurisprudence and legal issues concerning transgender individuals. However, there are many other sources available for such studies. ${ }^{19}$

14. Gender, MERRIAM-WEBSTER, https://www.merriam-webster.com/dictionary/gender [https: //perma.cc/NT9T-C847] (last visited Jan. 27, 2019).

15. See Sex Discrimination, BLACK's LAW DiCTIONARY (10th ed. 2014).

16. 42 U.S.C. $\$ 2000$ e-2(a) (2012); infra Section III.B.

17. See Univ. of Tex. Sw. Med. Ctr. v. Nassar, 570 U.S. 338, 372 (2013) (Ginsburg, J., dissenting) (using "gender" interchangeably with "sex" in stating that Title VII "§§ 2000e-2(a)-(d), which proscribe discrimination 'because of' race, color, religion, gender, or national origin"); Ledbetter v. Goodyear Tire \& Rubber Co., 550 U.S. 618, 659 (2007) (Ginsburg, J., dissenting) (stating that "[i]n this case, Ledbetter carried the burden of persuading the jury that the pay disparity she suffered was attributable to intentional sex discrimination" and also that "Ledbetter proved to the jury the following: She was a member of a protected class; she performed work substantially equal to work of the dominant class (men); she was compensated less for that work; and the disparity was attributable to gender-based discrimination") (emphasis added); Price Waterhouse v. Hopkins, 490 U.S. 228, 258 (1989) ("We hold that when a plaintiff in a Title VII case proves that her gender played a motivating part in an employment decision, the defendant may avoid a finding of liability only by proving by a preponderance of the evidence that it would have made the same decision even if it had not taken the plaintiff's gender into account.").

18. LGBTQ includes transgender, intersex and asexual individuals, as well as any other person who does not identify as male or female based on the traditional binary view of gender.

19. See generally Taylor Alyse Pack Ellis, Comment, Why the EEOC got it Right in Macy v. Holder: The Argument for Transgender Inclusion in Title VII Interpretation, 16 ScHOLAR: ST. MARY'S L. REV. \& SOC. JUST. 375 (2014) (arguing that Title VII prohibits discrimination towards transgender individuals); Jason Lee, Comment, Lost in Transition: The Challenges of Remedying Transgender Employment Discrimination under Title VII, 35 HARV. J.L. \& GENDER 423 (2012) (discussing legal theories that could be used to allow transgender individuals to bring cognizable Title VII claims). 
Finally, concerning pronouns, this Comment uses the preferred pronouns of the people discussed when available. Because this Comment addresses only those cases where the claimant identifies as either male or female, where the gender identity of a person or class of persons is unknown, his/her pronouns are used.

\section{BACKGROUND}

The background of Title VII and the jurisprudence interpreting it is a vital part of understanding how and why Title VII applies to discrimination based on sexual orientation. Section III.A first considers the origin of Title VII's prohibition because of sex and its effect on interpretation. Second, Section III.B considers the more modern application of Title VII to gender nonconformity and sexual orientationrelated issues. Then, Section III.C provides an overview of Hively and other cases where courts have recognized protection for lesbian, gay, and bisexual individuals under Title VII's sex discrimination prohibition. Finally, Section III.D explores the opposing argument in cases like Omnicom and Evans.

\section{A. The Misunderstood History of Title VII's Sex Discrimination Prohibition}

The legislative history (or lack thereof) of Title VII's prohibition on sex discrimination has often been used in interpreting the statute, usually to the effect of narrowing the scope of protection under the Act. ${ }^{20}$ In its earliest form, Title VII of the Civil Rights Act of 1964 did not even mention discrimination based on sex; instead Congress originally intended that the Act focus primarily on race. ${ }^{21}$ The "sex amendment," added only days before the vote on the bill, was originally "proposed by conservative opponents of the civil rights legislation who believed that it would lead to the defeat of the entire bill." ${ }^{22}$ This bit of legislative history is both misleading and extremely important to the analysis of

20. Mary Anne Case, Legal Protections for the "Personal Best" of Each Employee: Title VII's Prohibition on Sex Discrimination, the Legacy of Price Waterhouse v. Hopkins, and the Prospect of ENDA, 66 STAN. L. REV. 1333, 1342 (2014) (describing the Seventh Circuit's opinion in Ulane v. Eastern Airlines, Inc., 742 F.2d 1081, 1085 (7th Cir. 1984), which relied on a "dearth of legislative history" in finding Title VII did not cover transgender individuals).

21. Id. at 1338 .

22. Robert C. Bird, More than a Congressional Joke: A Fresh Look at the Legislative History of Sex Discrimination of the 1964 Civil Rights Act, 3 WM. \& MARY J. WOMEN \& L. 137, 137 (1997) (quoting Deborah Epstein, Can a "Dumb Ass Woman" Achieve Equality in the Workplace? Running the Gauntlet of Hostile Environment Harassing Speech, 84 GEO. L.J. 399, 409 n.62 (1996)). 
protections against discrimination based on sexual orientation under Title VII because courts have often taken it out of context and misconstrued it, ignoring the actual intent of the amendment and used to restrict sexbased protections under Title VII. ${ }^{23}$

Courts and scholars have long viewed the addition of "sex" to Title VII's list of protected classes as a congressional joke, made in an effort only to kill the bill entirely. ${ }^{24}$ While this may have been the initial view of the conservative Congressman who originally proposed the amendment, it is not the full story. ${ }^{25}$ Instead, "[a]ny attempt to add a sex amendment would have had to overcome a nearly overwhelming number of legislators willing to vote it down with little notice. Thus, the sex discrimination amendment could not have been added without strong multi-factional support." 26 Although Congressman Smith, who introduced the amendment, would have preferred to kill the bill altogether because of his racist views, it is also true that if the bill were to pass, he wanted sex added as a protected category. ${ }^{27}$ In fact, Smith had sponsored an Equal Rights Amendment for more than twenty years, and he supported the National Woman's Party. ${ }^{28}$ Further, the women in the House of Representatives were extremely serious in their support of the amendment. $^{29}$

Interestingly, the supporters of the sex amendment, whether conservative Southern Congressmen or moderate Northern Congresswomen, shared a common goal of expanding protection under Title VII to women. ${ }^{30}$ This unlikely bipartisan support allowed the Act to pass despite the last minute change. ${ }^{31}$ Indeed, as Professor Case points out, "Representative Smith may have been a racist, but he did not want 'his' women to take second place to men and women of other races," and

[f]or Representative Griffiths [a Congresswoman who supported the

Civil Rights Act], black women were also an important intersectional

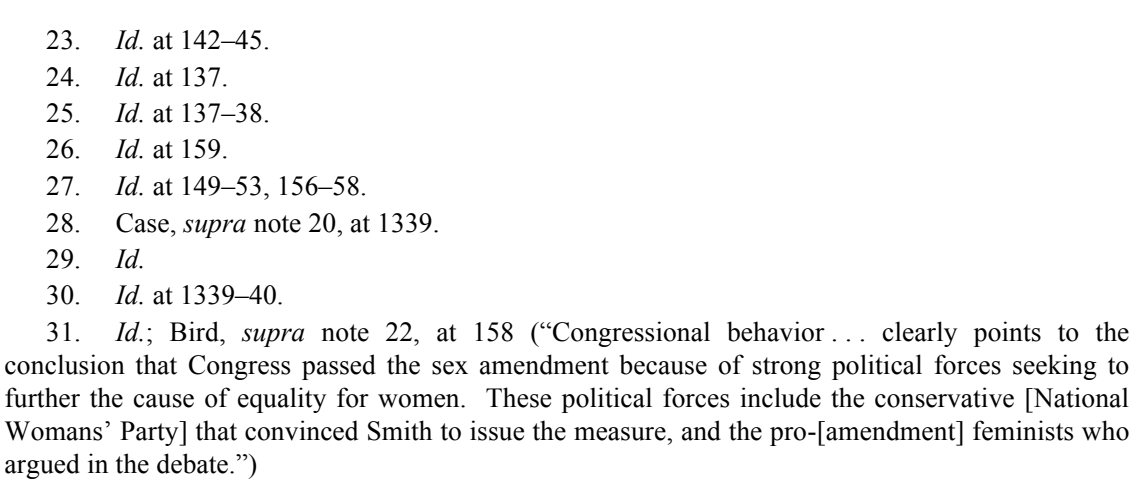


category. She stressed that black women needed a prohibition on sex discrimination were they to have any hope of equal employment opportunity and illustrated her point with examples from every class of employment. ${ }^{32}$

Thus, Congress's goal in passing Title VII with the sex amendment was not simply a political ploy, but rather an attempt to keep employers from disguising violations of the Act by simply discriminating based on a category not listed in the Act. ${ }^{33}$ Although a last-minute addition, the sex amendment proved to have anything but an insignificant impact.

\section{B. Price Waterhouse, Oncale, and the Expansion of Protection Under Title VII's Sex Discrimination Prohibition}

As Americans' views of women in the workplace, and gender in general, changed, the need to revisit the interpretation of the prohibition on sex discrimination grew. Over the years, courts have expanded the scope of Title VII to apply to much more than the clear-cut "fired for being female" scenario. ${ }^{34}$ For example, in Meritor Savings Bank, FSB v. Vinson, the Court stated that "[w]ithout question, when a supervisor sexually harasses a subordinate because of the subordinate's sex, that supervisor 'discriminate[s]' on the basis of sex," rejecting the argument that the prohibition was intended only to protect against "tangible," "economic" loss. ${ }^{35}$ Previously, in 1978, the Court in City of Los Angeles, Department of Water \& Power v. Manhart reasoned that "[i]n forbidding employers to discriminate against individuals because of their sex, Congress intended to strike at the entire spectrum of disparate treatment of men and women resulting from sex stereotypes."36 Reaffirming this decision, Price Waterhouse v. Hopkins set the stage for the current debate surrounding the scope of Title VII's protection for LGBTQ

32. Case, supra note 20 , at 1340 .

33. Id.

34. See, e.g., Meritor Sav. Bank, FSB v. Vinson, 477 U.S. 57, 64-66 (1986) (expanding Title VII's sex discrimination prohibition to hostile work environment claims); Newport News Shipbuilding \& Dry Dock Co. v. EEOC, 462 U.S. 669, 682-83 (1983) (holding that a company insurance plan that fully covered female employees' pregnancy costs but which limited pregnancy cost coverage for the spouses of male employees violates Title VII); City of L.A., Dep't of Water \& Power v. Manhart, 435 U.S. 702, 707 n.13 (1978) (finding a pension plan requiring female employees to make greater contributions than male employees because women statistically live longer than men violates Title VII as relying on sex stereotypes).

35. 477 U.S. at 64 (alterations in original).

36. 435 U.S. 702, 707 n.13 (quoting Sprogis v. United Air Lines, Inc., 444 F.2d 1194, 1198 (7th Cir. 1971)). 
individuals. $^{37}$

In Price Waterhouse v. Hopkins, Price Waterhouse accounting partnership denied Ann Hopkins, a female senior manager, a promotion after many of the partners took issue with her less-than-feminine qualities. $^{38}$ Hopkins sued Price Waterhouse under Title VII. ${ }^{39}$ While none of the partners explicitly suggested that Price Waterhouse deny Hopkins partnership because she was a woman, negative comments were overwhelmingly sex-based, under the guise of a critique of her "interpersonal skills." million contract with the Department of State, which was described as "an outstanding performance" by some partners, others suggested that Hopkins was too abrasive. ${ }^{41}$ One partner further stated that Hopkins could improve her chances at partnership by walking, talking, and dressing "more femininely," wearing makeup, and having her hair done. $^{42}$ This statement does not necessarily imply that the mere fact of being a woman entirely barred a person from partnership at Price Waterhouse, especially because no one alleged that the firm denied all women partnership positions. ${ }^{43}$ In fact, it seemed that Price Waterhouse's evaluating partners sought out more "feminine" behavior. ${ }^{44}$ Women who maintained a level of "femininity" at the firm were viewed favorably and able to succeed. ${ }^{45}$ However, women, like Hopkins, who did not adhere to traditional gender roles, were at a disadvantage in the Price Waterhouse partnership scheme. ${ }^{46}$ Although the mere fact of Hopkins's sex was not necessarily the reason for her denial of partnership, sex stereotyping likely was. ${ }^{47}$ Thus, the Court in Hopkins's case considered whether Title VII protects against this discrimination based on sex stereotypes, in addition to the most basic meaning of sex discrimination. ${ }^{48}$

37. See generally Camille Patti, Note, Hively v. Ivy Tech Community College: Losing the Battle but Winning the War for Title VII Sexual Orientation Discrimination Protection, 26 TUL. J.L. \& SEXUALiTy 133, 135-36 (2017).

38. 490 U.S. $228,232-35$ (1989)

39. Id. at $231-32$.

40. Id. at $234-35$.

41. Id. at 233-34.

42. Id. at 235 (quoting Hopkins v. Price Waterhouse, 618 F. Supp. 1109, 1117 (D.D.C. 1985)).

43. $I d$. at 236 .

44. Id.

45. $I d$.

46. See id. at 236-37.

47. Id. at 235-36.

48. Id. at 250 . 
The Supreme Court rejected the narrow interpretation of Title VII put forth by Price Waterhouse. Instead, it found that the text of Title VII means that "gender must be irrelevant to employment decisions," and that "to construe the words 'because of' as colloquial shorthand for 'butfor causation,' as does Price Waterhouse, is to misunderstand them." Further the court held that "we are beyond the day when an employer could evaluate employees by assuming or insisting that they matched the stereotype associated with their group" and that "an employer who acts on the basis of a belief that a woman cannot be aggressive, or that she must not be, has acted on the basis of gender." ${ }^{20}$ This holding allows us to see that when an employer discriminates against an employee because of their sexual orientation, that employee is also a victim of sex stereotyping.

Subsequently, the Supreme Court further clarified Title VII's sex discrimination provision in Oncale v. Sundowner Offshore Services. In Oncale, Joseph Oncale's male supervisors repeatedly subjected him to sexual harassment while working on an oil platform. ${ }^{51}$ Oncale complained, but his employer, Sundowner Offshore Services, took no remedial action against his harassers. ${ }^{52}$ After eventually quitting his job, Oncale sued Sundowner under Title VII, alleging that he faced discrimination because of his sex. ${ }^{53}$ The district court found that "Mr. Oncale, a male, has no cause of action under Title VII for harassment by male co-workers" and granted the defendant's motion for summary judgment; the Fifth Circuit Court of Appeals later affirmed. ${ }^{54}$

However, the Supreme Court disagreed with the Fifth Circuit's interpretation of Title VII. ${ }^{55}$ The Oncale opinion revolved around the plain meaning of Title VII's text. ${ }^{56}$ In the Court's opinion, Justice Scalia reemphasized important precedent concerning the interpretation of Title VII. ${ }^{57}$ First, the "terms" and "conditions" referred to in the first section of the Act are not to be construed in the "narrow contractual sense" but rather to cover all disparate treatment in the workplace. ${ }^{58}$ Second, the language "because of ... sex" appearing in both sections of the Act

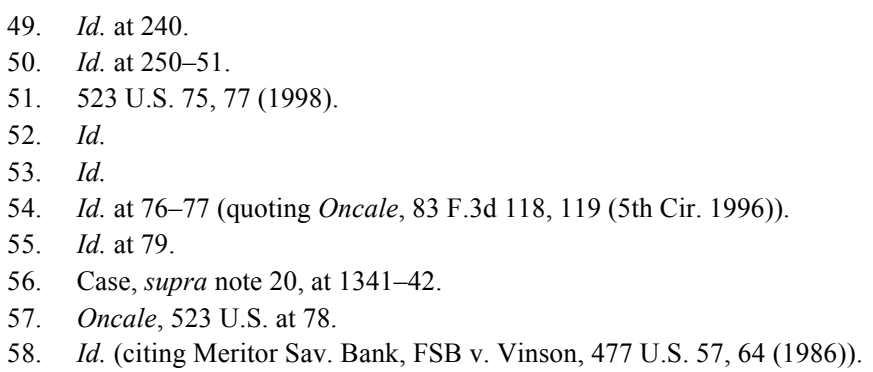


protects women as well as men. ${ }^{59}$ Importantly, Scalia responded directly to the argument that Congress did not intend Title VII to protect against same-sex harassment like the harassment Oncale experienced. $\mathrm{He}$ explained "statutory prohibitions often go beyond the principal evil to cover reasonably comparable evils, and it is ultimately the provisions of our laws rather than the principal concerns of our legislators by which we are governed." ${ }^{\prime 0}$ Some view Oncale as "a catalyst in finally pushing courts to reexamine their precedent on the coverage under Title VII of sexual minorities and gender-nonconforming employees in light of Hopkins." ${ }^{61}$ Thus, Price Waterhouse's broad interpretation of Title VII, combined with Oncale's reassurance that it may protect against evils not considered in 1964, including same-sex harassment, creates a strong argument for sexual orientation protection. Recently, courts have started to put these pieces together and articulate arguments for including sexual orientation in Title VII's definition of "sex."

C. Hively, the EEOC, and the Modern Argument for Protection against Discrimination based on Sexual Orientation

While most courts continue to rely on pre-Price Waterhouse precedent to hold that Title VII does not protect against discrimination based on sexual orientation, since Oncale and Price Waterhouse, some courts have found that Title VII does allow this protection. Most notable are the Equal Employment Opportunity Commission (EEOC) decision in Baldwin v. Department of Transportation and the Seventh Circuit opinion in Hively v. Ivy Tech Community College of Indiana. ${ }^{62}$ Additionally, the Second Circuit followed Hively's path and endorsed Baldwin in Zarda v. Altitude Express, Inc. ${ }^{63}$ These decisions represent a turn in Title VII interpretation in line with the precedent set in Oncale and Price Waterhouse, statutory construction, and the legislative intent of Title VII's prohibition on sex discrimination.

1. Baldwin and the EEOC's Authority

In Baldwin v. Department of Transportation, the EEOC broadly

\footnotetext{
59. Id. at 78 (citing Newport News Shipbuilding \& Dry Dock Co. v. EEOC, 462 U.S. 669, 682 (1983)).

60. Id. at 79 .

61. Case, supra note 20, at 1342.

62. Baldwin v. Foxx, No. 0120133080, 2015 WL 4397641, *2 (EEOC July 15, 2015); Hively v. Ivy Tech Cmty. Coll. of Ind., 853 F.3d 339, 341 (7th Cir. 2017) (en banc).

63. 883 F.3d 100, 107-08 (2d Cir. 2018) (en banc).
} 
proclaimed that claims of discrimination based on sexual orientation are cognizable under Title VII. ${ }^{64}$ The EEOC noted that discrimination because of sexual orientation is a "sex-based consideration" under Title VII and is based on the employees' failure to adhere to one of the most basic gender-based stereotypes: dating the opposite sex. ${ }^{65}$ In addition to this reasoning, the EEOC found that the Associational Theory used by courts to interpret Title VII's prohibition on race discrimination points towards prohibition of sexual orientation-based discrimination. The EEOC noted that Title VII's prohibition on race-based discrimination extends protection to those in interracial relationship and prohibits discrimination based on the associates of an employee, as in the case of interracial marriages. ${ }^{66}$ Under Price Waterhouse, "Title VII 'on its face treats each of the enumerated categories' - race, color, religion, sex, and national origin-'exactly the same.",67 Therefore, the EEOC decided, just as discrimination based on the race of an employee's partner is prohibited associational discrimination under Title VII, discrimination based on the sex of an employee's partner is associational discrimination prohibited under Title VII. ${ }^{68}$ Further, "the Baldwin panel directly criticized federal courts for failing to re-examine sexual orientation discrimination under Title VII, providing the impetus for courts to revisit the issue." $" 69$

The EEOC's decision in Baldwin does not bind federal courts interpreting Title VII. ${ }^{70}$ However, the EEOC's interpretation of Title VII may still be entitled to some level of deference by the Court. ${ }^{71}$ Depending on the specific circumstances, courts may use one of two tests to determine the level of deference they should give to an executive agency's interpretation of a statute. ${ }^{72}$ In cases where Congress has

\footnotetext{
64. Baldwin, 2015 WL 4397641, at*5.

65. Id.

66. Id. at *6.

67. Id. at *7 (quoting Price Waterhouse v. Hopkins, 490 U.S. 228, 243 n.9 (1989)).

68. Id.

69. Patti, supra note 37, at 134-35.

70. Melissa Hart, Skepticism and Expertise: The Supreme Court and the EEOC, 74 FORDHAM L. REV. 1937, 1937 (2006) ("To some extent, the Court's lack of deference to the EEOC is part of a broader picture: The Court has established a bifurcated structure of administrative deference that leaves much of the kind of interpretation that the EEOC most often engages in with the "power to persuade' but not the 'power to control." (quoting Skidmore v. Swift \& Co., 323 U.S. 134, 140 (1944))); Patti, supra note 37, at 134-35.

71. Patti, supra note 37 , at 138.

72. Bradley George Hubbard, Comment, Deference to Agency Statutory Interpretations First Advanced in Litigation? The Chevron Two-Step and the Skidmore Shuffle, 80 U. CHI. L. REV. 447, 451-52 (2013). See generally Chevron, U.S.A., Inc. v. NRDC, 467 U.S. 837 (1984); Skidmore v. Swift \& Co., 323 U.S. 134 (1944).
} 
delegated authority to interpret a statute to an executive agency, courts use the Chevron deference test. ${ }^{73}$ Chevron consists of a two-part test for determining the level of deference courts should give to an executive agency's interpretation of a statute. ${ }^{74}$ The Supreme Court held in Chevron, U.S.A., Inc. v. NRDC that:

When a court reviews an agency's construction of the statute which it administers ... 「andl the court determines Congress has not directly addressed the precise question at issue, the court does not simply impose its own construction on the statute, as would be necessary in the absence of an administrative interpretation. Rather, if the statute is silent or ambiguous with respect to the specific issue, the question for the court is whether the agency's answer is based on a permissible construction of the statute.

Courts have generally used this test to address agency interpretations stemming from "notice-and-comment rulemaking or formal adjudication. ${ }^{76}$

Further, a second test exists for use in those cases where Congress has not delegated authority-expressly or impliedly - to the executive agency: the Skidmore deference test. Courts use this test because even when executive agency has not been delegated the authority to interpret a statue, the agency interpretation "constitute[s] a body of experience and informed judgment to which courts and litigants may properly resort for guidance." In Skidmore v. Swift \& Co., the Supreme Court stated that courts should consider factors like "the thoroughness evident in its consideration, the validity of its reasoning, its consistency with earlier and later pronouncements, and all those factors which give it power to persuade" in determining the weight given to an executive agency's judgment. $^{78}$ The level of deference given to an agency under the Skidmore test is weaker than that given under the Chevron test, and is usually applied to "a wide variety of agency interpretations, ranging from opinion letters addressed to specific disputes to more generally applicable policy statements, agency manuals, and enforcement guidelines. ${ }^{, 79}$

73. Chevron, 467 U.S. at 842 (noting the test applies “[w]hen a court reviews an agency's construction of the statute which it administers").

\footnotetext{
74. Id. at $842-43$.

75. $I d$. at 843 (citations omitted).

76. Hart, supra note 70, at 1940.

77. Skidmore, 323 U.S. at 140.

78. Id.

79. Hart, supra note 70, at 1941.
} 
Despite these tests, the Court is generally hesitant to even address the level of deference that should be given to an agency much less actually give that deference to the agency. ${ }^{80}$ In fact, over the years, the Court has added what is often referred to as "Chevron Step Zero." 81 Step Zero addresses, as a threshold matter, whether agency interpretations should be analyzed under Chevron, as opposed to some lower standard. ${ }^{82}$ For example, in Christensen v. Harris County and United States v. Mead Corp., the Court determined "Chevron's high level of deference applies only to agency interpretations that have the "force of law." "83 The Court further complicated things in Barnhart $v$. Walton, which laid out factors used by the Court in deciding whether to apply the Chevron test. ${ }^{84}$ However, despite the decisions in Mead and Christensen, the Court later applied the Chevron test to an EEOC interpretation without any mention of a "force of law" requirement. In Chevron U.S.A. Inc. v. Echazabal, the Court simply stated that "[s]ince Congress has not spoken exhaustively on threats to a worker's own health, the agency regulation can claim adherence under the rule in Chevron . . ." 85

Interestingly, the Court has never applied the Chevron deference test to an antidiscrimination case under Title VII, although it has applied the test to two antidiscrimination cases under the ADA and the ADEA, ultimately choosing to defer to the EEOC in one. ${ }^{86}$ The Supreme Court has frequently applied the Skidmore deference test to antidiscrimination cases, however, and "[i]n two Title VII cases, the Court devoted considerable discussion to the administrative deference question." 87 Although neither of these cases found that the EEOC's interpretation was entitled to deference, both cases "garnered a strong dissenting opinion that also applied the same Skidmore deference standard but reached a contrary conclusion as to the persuasiveness of the agency's views. For example, in General Electric Co. v. Gilbert, the Court examined an

\footnotetext{
80. Id. at $1942-43$.

81. Ryan H. Nelson, Sexual Orientation Discrimination Under Title VII After Baldwin v. Foxx, 72 WASH. \& LEE L. REV. ONLINE 255, 259 (2015).

82. Id.

83. Thomas W. Merrill \& Kathryn Tongue Watts, Agency Rules with the Force of Law: The Original Convention, 116 HARV. L. REV. 467, 470 (2002) (quoting United States v. Mead Corp., 533 U.S. 218, 226-27 (2001); Christensen v. Harris Cty., 529 U.S. 576, 587 (2000)).

84. Nelson, supra note 81, at 261.

85. 536 U.S. $73,84(2002)$.

86. Hart, supra note 70, at 1944-45 (citing Echazabal, 536 U.S. at 84 (deferring to the EEOC's interpretation of the ADA); Pub. Emps. Ret. Sys. v. Betts, 492 U.S. 158, 170 (1989) (declining to defer to the EEOC's ADEA interpretation)).

87. Id. at 1945 .

88. Id.
} 
EEOC interpretive guideline that construed Title VII's ban on sex discrimination as requiring equal coverage for work loss from pregnancy and work loss from other temporary disabilities. ${ }^{89}$ Although the Court ultimately did not give deference to the interpretive guideline ${ }^{90}$ Justice Brennan argued that the issue at hand was "a paradigm example of the type of complex economic and social inquiry that Congress wisely left to resolution by the EEOC pursuant to its Title VII mandate."

\section{Hively's Reconsideration of Precedent}

In Hively, Kimberly Hively alleged that her employer, Ivy Tech Community College, denied her promotions for full-time employment because she was openly gay. ${ }^{92}$ Hively claimed that the discrimination she faced was a form of sex discrimination. ${ }^{93}$ Ivy Tech successfully moved for a dismissal claiming that Title VII does not protect employees from discrimination based on sexual orientation. ${ }^{94}$ The Seventh Circuit upheld the decision in a three-judge panel. ${ }^{95}$ Later, sitting en banc, the same court overturned the panel's decision, creating the circuit split that exists today. ${ }^{96}$ The court in Hively specifically reasoned that its review of the case was justified to bring the circuit's law into "conformity with the Supreme Court's teachings." 97 Relying mainly on the sexstereotyping theory of sex discrimination used by the Supreme Court in Price Waterhouse, the Seventh Circuit held that

[A] policy that discriminates on the basis of sexual orientation does not affect every woman, or every man, but it is based on assumptions about the proper behavior for someone of a given sex.... Any discomfort, disapproval, or job decision based on the fact that the complainantwoman or man-dresses differently, speaks differently, or dates or marries a same-sex partner, is a reaction purely and simply based on sex. That means that it falls within Title VII's prohibition against $\operatorname{sex}_{98}$ discrimination, if it affects employment in one of the specified ways.

\footnotetext{
89. Id. at 1945-46 (citing Gen. Elec. Co. v. Gilbert, 429 U.S. 125, 140 (1976)).

90. Id. at 1946 (citing Gilbert, 429 U.S. at 142-43).

91. Id. (quoting Gilbert, 429 U.S. at 155 (Brennan, J., dissenting)).

92. Hively v. Ivy Tech Cmty. Coll. of Ind., 853 F.3d 339, 341 (7th Cir. 2017) (en banc).

93. Id.

94. Id.

95. Hively v. Ivy Tech Cmty. Coll., S. Bend, 830 F.3d 698, 701-02 (7th Cir. 2016), rev'd en banc sub nom. Hively, 853 F.3d 339.

96. Hively, 853 F.3d at $351-52$.

97. Id. at 343 .

98. Id. 346-47.
} 
However, this is not the only reasoning used by members of the Hively court. In addition to majority's finding that discrimination based on sexual orientation relies on sex stereotyping, both concurrences also examined the plain meaning of the text. ${ }^{99}$ In doing so, the concurring judges argued that it is entirely impossible to discriminate against an individual based on their sexual orientation without discriminating based on their sex. ${ }^{100}$ One could not, after all, deduce the sexual orientation of an employee without first considering that employee's sex. ${ }^{101}$ Therefore, the Hively court held that Title VII not only prohibits discrimination based on sexual orientation because of the stereotyping interpretation in Price Waterhouse but also because of its plain meaning. The EEOC's position in Baldwin, as well as the court's decision in Hively, summarize the modern arguments for protection against sexual orientation-based discrimination under Title VII.

Similarly, in Zarda, the Second Circuit, sitting en banc, ruled that claims of discrimination based on sexual orientation are cognizable under Title VII, overruling its previous cases on the matter. ${ }^{102}$ Altitude Express, a skydiving company, fired Donald Zarda, a skydiving instructor, after he mentioned that he was gay to a client. ${ }^{103}$ Zarda argued that all of the straight men at Altitude Express made comments about their sexuality, yet Altitude only punished him for such comments. ${ }^{104}$ This, Zarda said, was impermissible because Altitude discriminated against him based on his failure to adhere to sex stereotypes and because of his sexual orientation. ${ }^{105}$ The en banc court agreed, stating " $[\mathrm{w}] \mathrm{e}$ now conclude that sexual orientation discrimination is motivated, at least in part, by sex and is thus a subset of sex discrimination." 106 The court emphasized that the primary factor to consider in deciding whether discrimination was "because of ... sex" was whether "sex... was a motivating factor for any employment practice." 107 Further, the various opinions in the case also included endorsements of the sex-stereotyping and associational analyses addressed below. ${ }^{108}$ The court focused on Supreme Court cases holding

\footnotetext{
99. Id. at 356 (Posner, J., concurring).

100. Id. at 358 (Flaum, J., concurring).

101. Id. at 358 .

102. 883 F.3d 100, 107-08 (2d Cir. 2018) (en banc).

103. Id. at 108 .

104. Id. at 109 .

105. Id.

106. Id. at 112 .

107. Id. at 111-12 (quoting 42 U.S.C. § 2000e-2(m) (2012)).

108. Id. at 119-28; see infra Sections IV.B.2-3.
} 
that sex discrimination existed even where the employer considered factors other than sex in its decisions, and where the situation was likely not envisioned by the authors of Title VII, such as sexual harassment of men by other men. ${ }^{109}$ Zarda's outcome further reaffirms that courts should reconsider Title VII analysis in light of the more recent Supreme Court cases on sex discrimination.

\section{Evans and the Modern Argument Against Protection for} Discrimination Based on Sexual Orientation

The Eleventh Circuit, on the other hand, has found that Title VII does not apply to discrimination based on sexual orientation. In Evans v. Georgia Regional Hospital and in Christiansen v. Omnicom Group Inc., the Eleventh and the Second Circuits, respectively, refused to allow claims under Title VII based on discrimination because of sexual orientation. ${ }^{110}$ These cases and their reasoning are discussed in detail below.

In Evans v. Georgia Regional Hospital, Jameka Evans alleged that her employer, Georgia Regional Hospital, discriminated against her because she is a lesbian and that she did not conform to female gender stereotypes. ${ }^{111}$ At the hospital, Evans was harassed, denied equal pay, and physically assaulted until she quit her job. ${ }^{112}$ Evans sued the hospital, arguing Title VII prohibits discrimination based on failure to adhere to gender norms, including her sexual orientation, and that Title VII also prohibits discrimination based on sexual orientation itself. ${ }^{113}$ The Eleventh Circuit chose, in a rather unnatural manner, to treat these complaints as entirely separate. ${ }^{114}$ That is, the court recognized that Title VII prohibits discrimination based on failure to adhere to gender norms, but refused to acknowledge that the Act prohibits discrimination based on sexual orientation. ${ }^{115}$ This analysis likely stems from a 1979 case the court cited in its decision, which states "discharge for homosexuality is not prohibited by Title VII." "116 Notably, the court decided that 1979 case

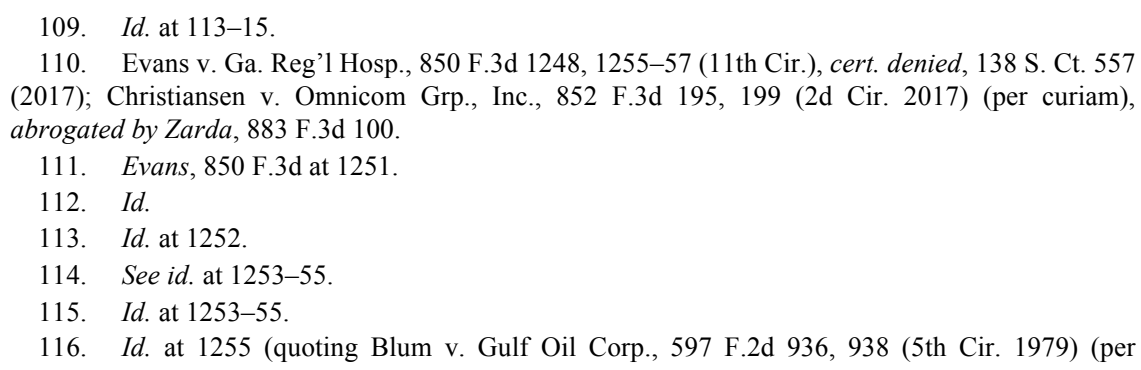


before both Price Waterhouse and Oncale. Yet, the court in Evans held that the Oncale and Price Waterhouse decisions did not change its analysis. $^{117}$

Before Zarda, the Second Circuit embarked on a similar path in its analysis of Omnicom. In Omnicom, Matthew Christiansen, an openly gay man, alleged that he was subjected to a "pattern of humiliating harassment targeting his effeminacy and sexual orientation" by his supervisor. ${ }^{118}$ Christiansen brought a claim under Title VII stating that his employer discriminated against him based on his failure to conform to gender stereotypes, and a sexual orientation discrimination claim under New York law. ${ }^{119}$ Like the court in Evans, the Omnicom court found that it could not reconsider previous Circuit decisions absent an en banc review, and found, perhaps even more directly than in Evans, that "being gay, lesbian, or bisexual, standing alone, does not constitute nonconformity with a gender stereotype that can give rise to a cognizable gender stereotyping claim." 120 The precedent cited to support the Second Circuit here specifically stated that Price Waterhouse "would not bootstrap protection for sexual orientation into Title VII because not all homosexual men are stereotypically feminine."121 These cases, and others that have found Title VII does not protect against discrimination based on sexual orientation, rely on precedent to work around the reasoning presented in Baldwin, Price Waterhouse, and Oncale. The following Sections discuss the flaws in such analyses.

\section{ANALYSIS}

Considering the text of Title VII and the Supreme Court's findings in Oncale and Price Waterhouse, it becomes clear that the Seventh Circuit in Hively properly interpreted the statute in finding that it prohibits

curiam)). See also id. n.4 (noting that in Bonner v. City of Prichard, 661 F.2d 1206, 1209 (11th Cir. 1981) (en banc), the Eleventh Circuit adopted as binding precedent all Fifth Circuit precedent decided on or before September 30, 1979).

117. Id. at 1256 (noting that as Oncale and Price Waterhouse did not directly address Title VII's applicability to sexual orientation claims, they were distinguishable and did not compel the court to overrule its precedent).

118. Christiansen v. Omnicom Grp., Inc., 852 F.3d 195, 198 (2d Cir. 2017) (per curiam), abrogated by Zarda v. Altitude Express, Inc., 883 F.3d 100 (2d Cir. 2018) (en banc).

119. Id. at 198.

120. Id. at 199, 201. Rather, the test is based not on sexual orientation but whether a plaintiff's actions comport with assumptions of the plaintiff's gender (e.g., a more masculine or feminine man or a more masculine or feminine woman). Id. at 200-01 (noting that the Price Waterhouse plaintiff's sexual orientation was irrelevant).

121. Id. at 200 (quoting Simonton v. Runyon, 232 F.3d 33, 38 (2d Cir. 2000)). 
sexual orientation discrimination. This interpretation is preferable to that of Omnicom and Evans for four reasons. First, the current precedent and analysis applied by courts denying sexual orientation protection under Title VII is faulty, inconsistent, and ignores the weight courts should give to the Baldwin decision. Second, an analysis of the statutory construction of Title VII under Price Waterhouse and Oncale leads to the conclusion that the Act prohibits sexual orientation discrimination. Third, the legislative intent of the Act, and specifically the "because of ... sex" language, supports a finding that sexual orientation discrimination is prohibited under the Act. Finally, determining the meaning of sex discrimination under Title VII has important policy implications including increasing consistency of protection for employees throughout the United States and of enforcement of Title VII.

\section{A. Fixing Flawed Analyses: Addressing the Problems of Precedent, Absurd Results, and Baldwin.}

Many of the federal courts addressing whether Title VII encompasses sexual orientation claims have failed to acknowledge the rationality of allowing this protection by simply relying on precedent and engaging in work-around analyses. ${ }^{122}$ Despite Price Waterhouse's prohibition on sex stereotyping, courts continue to find ways to work around expanding the protection of Title VII, all of which are unsustainable and less reasonable than a Baldwin-style analysis. First, the court may simply state that it cannot overrule its older precedent. ${ }^{123}$ Second, the court may assume that all Title VII claims by lesbian, gay, or bisexual plaintiffs are sexual orientation claims disguised as sexstereotyping claims and be hesitant to hear them. ${ }^{124}$ Or finally, the court may engage in an unusual analysis of describing gay or lesbian stereotypes and refusing to hear cases addressing discrimination based solely on those stereotypes. ${ }^{125}$ In addition, none of these courts have

122. See Evans v. Ga. Reg'1 Hosp., 850 F.3d 1248, 1255 (11th Cir. 2017) (stating the court could not overturn precedent absent an en banc or Supreme Court decision overruling the past case), cert. denied, 138 S. Ct. 557 (2017); Omnicom Grp., Inc., 852 F.3d at 199 (same).

123. See, e.g., id.; Hamm v. Weyauwega Milk Prods., Inc., 332 F.3d 1058, 1062 (7th Cir. 2003), abrogated by Hively v. Ivy Tech Cmty. Coll. of Ind., 853 F.3d 339 (7th Cir. 2017) (en banc). Although the Hamm court never explicitly stated its inability to overturn precedent, it did not analyze the continued viability of that precedent.

124. See, e.g., Hamm, 332 F.3d at 1065 ("Unlike Doe and Azteca, where the plaintiffs presented additional evidence that the harassment implicated sex rather than sexual orientation, Hamm's allegations are linked either to his coworkers' perceptions of his work performance or his sexual orientation.").

125. See, e.g., Anderson v. Napolitano, No. 09-60744-CIV, 2010 WL 431898, at *6 (S.D. Fla. 
given the EEOC's Baldwin decision the weight it deserves under either the Chevron or Skidmore tests. All of these routes ignore the logical arguments for expanding the protection of Title VII and further complicate the situation. For this reason, these cases should not be viewed as dispositive on the issue of Title VII and sexual orientation discrimination.

\section{Problematic Precedent}

Some courts have held that claims based on sexual orientation discrimination are not cognizable under Title VII based on earlier precedent. ${ }^{126}$ For example, the Second Circuit, in Omnicom, stated that the district court's analysis was incorrect purely because previous cases had found that "being gay, lesbian, or bisexual, standing alone, does not constitute nonconformity with a gender stereotype that can give rise to a cognizable gender stereotyping claim," without any explanation as to why this is. ${ }^{127}$ Further, neither of the two prior cases to which the court referred explain why the idea that women should date men and men should date women does not qualify as sex-based stereotypes. ${ }^{128}$ In fact, one of the cases, Simonton v. Runyon, states that the plaintiff "relies on Price Waterhouse v. Hopkins to argue that the abuse he suffered was discrimination based on sexual stereotypes, which may be cognizable as discrimination based on sex." 29 The court found "this argument more substantial than Simonton's previous two arguments, but not sufficiently pled in this case," and that the court therefore "express[ed] no opinion as to how this issue would be decided in a future case in which it is squarely presented and sufficiently pled." 130

The other case that the Omnicom court relied on was Dawson $v$. Bumble \& Bumble. ${ }^{131}$ Not surprisingly, the court here also stated that

Feb. 8, 2010).

126. Evans, 850 F.3d at 1255; Omnicom Grp., Inc., 852 F.3d at 199.

127. Omnicom Grp., Inc., 852 F.3d at 201 (first citing Dawson v. Bumble \& Bumble, 398 F.3d 211 (2d Cir. 2005); then citing Simonton v. Runyon, 232 F.3d 33 (2d Cir. 2000)). The Second Circuit recently overruled both Dawson and Simonton. See Zarda v. Altitude Express, Inc., 883 F.3d 100 (2d Cir. 2018) (en banc).

128. Dawson, 398 F.3d at 218, 221 (2d Cir. 2005) (stating that sexual orientation claims can easily be styled as sex-stereotyping claims before noting the absence of evidence that any hostility the plaintiff suffered was attributable to her non-conforming dress style); Simonton, 232 F.3d at 3738 (avoiding the issue as the plaintiff did not assert sufficient facts or make the argument in the lower court).

129. Simonton, 232 F.3d at 37 (citation omitted).

130. Id.

131. 398 F.3d 211. 
"gender stereotyping claims can easily present problems for an adjudicator." 132 This is for the simple reason that "[s]tereotypical notions about how men and women should behave will often necessarily blur into ideas about heterosexuality and homosexuality."133 While Dawson is more thorough on this point than Simonton, the court focuses much of its analysis on the idea that gay, lesbian, or bisexual individuals are "using" the gender stereotyping theory to "hide" their "unprotected" sexual orientation claims. ${ }^{134}$ However, again, the court does not consider whether a claim under Title VII based on sexual orientation discrimination is necessarily a gender-stereotyping claim, other than to state simply that it is not. ${ }^{135}$ Therefore, the court should not have considered Simonton and Dawson dispositive on the issue of whether sexual orientation is a sex-based stereotype leading to a cognizable claim under Title VII.

The EEOC's opinion in Baldwin, criticizing the Seventh Circuit before its en banc Hively decision, also illustrates the precedent problem. There, the EEOC stated:

A review of cases cited for the proposition that sexual orientation is excluded from Title VII reveals that many courts simply cite earlier and dated decisions without any additional analysis. For example, in a brief to the Seventh Circuit Court of Appeals requesting rehearing based on various broad declaratory statements that Title VII does not cover sexual orientation, the EEOC pointed out that only one previous Seventh Circuit case had analyzed the question of coverage of sexual orientation discrimination under Title VII and that case, decided in 1984, had not been reviewed in light of subsequent decisions such as Price Waterhouse. Instead, a string of Seventh Circuit panel decisions had simply reiterated the holding in the first case without any further discussion.

Court opinions that merely contain conclusory statements without reasoning or justification, are hardly valuable precedent. Thus, Federal Courts of Appeals, when possible, should feel empowered to overturn precedent that does not engage in meaningful analysis considering Price Waterhouse, Oncale, and Baldwin.

\footnotetext{
132. Id. at 218 .

133. Id. (quoting Howell v. N. Cent. Coll., 320 F. Supp. 2d 717, 723 (N.D. Ill. 2004)).

134. See id. at 218-19.

135. See id. at 217-18 (noting that the court is unsure which allegations relate to the plaintiff's gender stereotype versus her sexual orientation claim).

136. Baldwin v. Foxx, No. 0120133080, 2015 WL 4397641, at*8 n.11 (EEOC July 15, 2015).
} 


\section{Sexual Orientation as the Deciding Factor}

Some have approached the post-Price Waterhouse "confusion" of sex stereotyping and sexual orientation by viewing all sex-stereotyping claims brought by gay, lesbian, or bisexual individuals as sexual orientation discrimination cases in disguise. ${ }^{137}$ Thus, where a man is fired for wearing nail polish, he would have a sex-stereotyping claim under Title VII only if he were straight, while a gay man would not be protected. Judge Posner addresses this odd conclusion in his concurrence in Hamm v. Weyauwega Milk Prod. ${ }^{138}$ Judge Posner points out that the court's "extension" of Price Waterhouse would mean "that the law protects effeminate men from employment discrimination, but only if they are (or are believed to be) heterosexuals" and that "to impute such a distinction to the authors of Title VII is to indulge in a most extravagant legal fiction." 139 Courts, including the Supreme Court, should not continue down this "absurd" path and should instead adopt the logical reasoning used in Baldwin and Hively.

\section{Stereotyping by the Court}

A similar and equally odd path that some courts have taken is to decide sex-stereotyping claims based on whether the stereotype is one typically associated with gay men or lesbian women. ${ }^{140}$ Courts engaging in this type of analysis would hold that if the stereotype is one associated with gay men or lesbian women then there is no claim under Title VII. ${ }^{141}$ For example, the now-overturned Hively panel pointed out that a Florida court held that "because a gay employee had a lisp, and a lisp is a stereotype associated with gay men rather than women, the discrimination the employee faced was not because of sex," and

137. See Hively v. Ivy Tech Cmty. Coll., S. Bend, 830 F.3d 698, 705 (7th Cir. 2016) (“As we will describe below, courts have gone about this task in different ways - either by disallowing any claims where sexual orientation and gender non-conformity are intertwined, (and, for some courts, by not allowing claims from lesbian, gay, or bisexual employees at all), or by trying to tease apart the two claims and focusing only on the gender stereotype allegations. In both methods, the opinions tend to turn circles around themselves because, in fact, it is exceptionally difficult to distinguish between these two types of claims."), rev'd en banc sub nom. Hively v. Ivy Tech Cmty. Coll. of Ind., 853 F.3d 339 (7th Cir. 2017).

138. Hamm v. Weyauwega Milk Prods., Inc., 332 F.3d 1058, 1067 (7th Cir. 2003) (Posner, J., concurring), abrogated by Hively, 853 F.3d 339.

139. Id.

140. Hively, 830 F.3d at 698 (citing Anderson v. Napolitano, No. 09-60744-CIV, 2010 WL 431898, at *6 (S.D. Fla. Feb. 8, 2010)); Patti, supra note 37, at 141 (noting cases dismissed because plaintiffs did not display a sufficient number of stereotypes).

141. Hively, 830 F.3d at 709 (citing Napolitano, 2010 WL 431898, at *6). 
therefore not cognizable under Title VII. ${ }^{142}$ Here, a gay man mocked for his lisp does not have a cognizable claim under Title VII but a gay man mocked for wearing lipstick does. ${ }^{143}$ Such a distinction is entirely arbitrary and does not fulfill the purpose of Title VII. ${ }^{144}$ Continuing to separate sex stereotyping from sexual orientation will only encourage courts to engage in this kind of absurd analysis. Instead, courts should simply look to the rational statutory construction of the statute and find that Title VII protects against discrimination based on sexual orientation.

\section{The EEOC's Deserved Deference}

The EEOC and its decision in Baldwin are entitled to some deference by the federal courts in interpreting Title VII, and more specifically, the questions of whether it prohibits discrimination based on sexual orientation. As stated above, courts analyzing questions of Title VII interpretation could use one of two tests to determine the level of deference that should be afforded to EEOC decisions: the Chevron or Skidmore deference tests. ${ }^{145}$ Because the Supreme Court's instruction on deciding which test to use is not entirely clear, there is a possibility, although slight, that the EEOC's Baldwin interpretation could be given Chevron deference. ${ }^{146}$ This is because the Barnhart factors, as applied to Baldwin, weigh in favor of Chevron deference. ${ }^{147}$ Nevertheless, because the EEOC rules and regulations do not have the "force of law," it seems unlikely that, after Mead and Omnicom, Baldwin would be given controlling weight by the Court. ${ }^{148}$ But, if the Court chose to focus on the Barnhart factors, the Baldwin decision would be entitled to deference under the Chevron test, as the EEOC's interpretation in Baldwin meets

\footnotetext{
142. Patti, supra note 37, at 140-41 (citing Hively, 830 F.3d at 709).

143. Id.

144. See Peter Brandon Bayer, Debunking Unequal Burdens, Trivial Violations, Harmless Stereotypes, and Similar Judicial Myths: The Convergence of Title VII Literalism, Congressional Intent, and Kantian Dignity Theory, 89 ST. JOHN's L. REV. 401, 402 (2015) ("The purpose of the law is simple.... [T] he only limit to a man's hope for happiness ... shall be his own ability." (quoting President Lyndon B. Johnson, Radio \& Television Remarks upon Signing the Civil Rights Bill, 2 PUB. PAPERS 842, 843 (July 2, 1964) (transcript available at https://millercenter.org/thepresidency/presidential-speeches/july-2-1964-remarks-upon-signing-civil-rights-bill [https://perma.cc/P4FF-TNZU]))).

145. See supra notes 70-79 and accompanying text.

146. Merrill \& Watts, supra note 83, at 480 (noting that Chevron and Mead permit agencies to adopt rules and regulations, not legislative rules).

147. Nelson, supra note 81, at 263-67.

148. Gen. Elec. Co. v. Gilbert, 429 U.S. 125, 141-42 (1976) (applying Skidmore deference because Congress had not granted the EEOC authority to enact rules and regulations interpreting Title VII).
} 
most of these factors. ${ }^{149}$

Even if a court does not believe the Baldwin decision passes the Chevron test, it should still give the decision a considerable amount of weight under the Skidmore test. Under Skidmore, an interpretation is entitled to some, but less than controlling, weight. ${ }^{150}$ While not controlling, these interpretations "do constitute a body of experience and informed judgment to which courts and litigants may properly resort for guidance." 151 As mentioned above, the weight of such interpretations is determined by the following factors: "the thoroughness evident in its consideration, the validity of its reasoning, its consistency with earlier and later pronouncements, and all those factors which give it power to persuade." "152 These factors weigh heavily in favor of Baldwin and, as such, the court should give the EEOC's interpretation great weight.

The first, second, and fourth factors weigh in favor of the Baldwin decision. While these factors, especially the first two, are rather subjective, the Baldwin decision appears to be thorough and wellreasoned, relying on substantial precedent and addressing both cases that support its decisions and cases that have disagreed with it. ${ }^{153}$ Additionally, the fact that many cases disagreeing with Baldwin do so on the basis of pre-Price Waterhouse precedent and flawed uses of stereotyping only further shows that Baldwin's reasoning is more valid than the awkward analysis these courts are attempting to apply. ${ }^{154}$ Lastly, the en banc Hively court used the same reasoning as Baldwin and specifically mentioned the Baldwin decision as instructive. ${ }^{155}$ This only adds to the Baldwin decision's power to persuade.

The third factor, however, is less helpful to Baldwin's reasoning. Unfortunately, the EEOC has not been consistent in its interpretation of Title VII's sex discrimination prohibition, which Baldwin addresses. ${ }^{156}$ However, because three of the four Skidmore factors weigh in favor of giving weight to Baldwin, courts should still give ample weight to this EEOC decision.

\footnotetext{
149. Nelson, supra note 81, at 263-67 (noting that three of the five Barnhart factors weigh in favor of Chevron deference).

150. Skidmore v. Swift \& Co., 323 U.S. 134, 140 (1944).

151. Id.

152. Id.

153. Baldwin v. Foxx, No. 0120133080, 2015 WL 4397641, at *8-9, *8 n.11 (EEOC July 15, 2015).

154. See supra Sections IV.A.1-3.

155. Hively v. Ivy Tech Cmty. Coll. of Ind., 853 F.3d 339, 344 (7th Cir. 2017) (en banc). Compare id., with Baldwin, 2015 WL 4397641, at *2.

156. Baldwin, 2015 WL 4397641, at*9 n.13.
} 
While Baldwin should be given some weight by courts, the level of deference it ultimately receives is not dispositive here. Even absent some deference, courts should still reach Baldwin's conclusion through their own reasoning. However, if a court is equally swayed by arguments for and against including sexual orientation in Title VII's prohibition on sex discrimination, the weight given to the Baldwin interpretation could and indeed should certainly tip the scales in favor of inclusion.

\section{B. Interpreting Title VII: Plain Meaning, Sex Stereotyping, and the} Associational Theory

When the Supreme Court addresses the interpretation of Title VII, it should hold that the sex discrimination prohibition includes discrimination based on sexual orientation. First, the plain meaning of the statute bans such discrimination. Second, discrimination based on sexual orientation is discrimination based on sex stereotyping and therefore violates Title VII under Price Waterhouse. Third, under the Associational Theory and Loving $v$. Virginia, discrimination based on the sex of one's partner violates Title VII's prohibition on sex discrimination. Fourth, although the Court may expand Title VII beyond the specific meaning members of Congress may have had in mind when they passed the Act, the Court should interpret Title VII in line with its broad original purpose of providing equality and protection from discrimination in the workplace. Lastly, the Court should consider the important policy reasons for holding that Title VII prohibits discrimination based on sexual orientation.

\section{Plain Meaning}

To determine the plain meaning of Title VII, we must look to the text in conjunction with the Supreme Court's interpretation of the statute. The plain meaning of Title VII's prohibition on sex discrimination includes a prohibition on discrimination based on sexual orientation. Perhaps the most basic canon of statutory construction is that where the plain language of a statute is clear, a court must give it effect. ${ }^{157}$ Title VII clearly states that discrimination "because of... sex" is

157. See Felix Frankfurter, Some Reflections on the Reading of Statutes, 47 Colum. L. REV. 527, 536 (1947). See also Kingdomware Techs., Inc. v. United States, 136 S. Ct. 1969, 1976 (2016) ("If the statutory language is unambiguous and "the statutory scheme is coherent and consistent... [t]he inquiry ceases." (quoting Barnhart v. Sigmon Coal Co., 534 U.S. 438, 450 (2002))). 
prohibited. ${ }^{158}$ It is true that regarding plain meaning, "the cases speak of the 'meaning of common understanding,' 'the normal and spontaneous meaning of language,' 'the common and appropriate use,' 'the natural straightforward and literal sense,' and similar variants."159 However, considering the extent of adjudication on Title VII, the question is not simply what the common person considers the definition of "sex" to be but rather "how to interpret the statute in light of the guidance the Supreme Court has provided." 160 The Hively Court addressed the argument that the common meaning of "sex" does not include sexual orientation, stating that "the dissent postulates that it is implausible that a reasonable person in 1964 could have understood discrimination based on sex to include sexual orientation discrimination. But that reasonable person similarly may not have understood it to include sexual harassment," which the Supreme Court has maintained is part of sex discrimination since at least $1986 .{ }^{161}$

In Price Waterhouse, the Court held that the prohibition on sex discrimination means that an employer may not make employment decisions based on "sex-based considerations."162 Further, Justice Ginsburg spoke to the plain meaning of Title VII in Harris v. Forklift Systems, Inc., when she stated that "the critical issue, Title VII's text indicates, is whether members of one sex are exposed to disadvantageous terms or conditions of employment to which members of the other sex are not exposed." "163

Sexual orientation discrimination fits both of these definitions. First, sexual orientation is inherently a "sex-based consideration" because one cannot define a person as gay, lesbian, or bisexual without first knowing that person's sex. ${ }^{164}$ Thus, it is impossible to say that an employer was able to discriminate based on the sexual orientation of an employee without considering that employee's sex. ${ }^{165}$ To attempt to separate sexual orientation from sex is simply an attempt to restrict unnecessarily

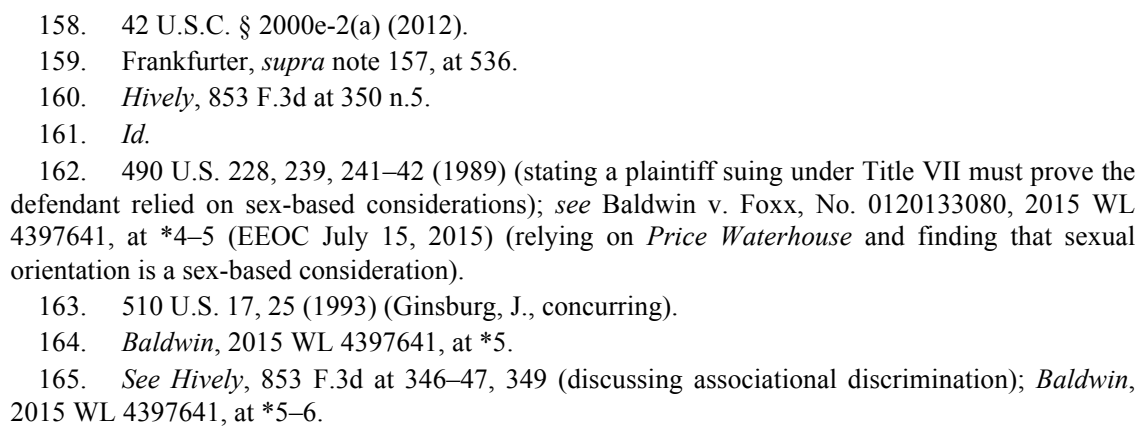


the application of the plain language of Title VII. Second, fitting with Justice Ginsburg's reiteration of the plain meaning of Title VII, discrimination based on sexual orientation treats two similarly situated employees differently based only on their sex. ${ }^{166}$ That is, when an employer fires a male employee married to another male but retains a female employee married to a male, that employer treats those similarly situated individuals differently purely because of the their sex. ${ }^{167}$ If the former employee had been a female, she would not have been fired. Thus, the cases mentioned above have shown that the plain meaning of "because of ... sex" in Title VII is any discrimination relying on "sexbased considerations" or any treatment that leaves a member of one sex at a disadvantage when a member of the opposite sex would not be. Under that meaning, it is clear that to discriminate against a person based on his or her sexual orientation is to discriminate based on sex.

Some critics have attempted to reason that the "similarly situated individuals" that the court should be comparing in this case are a gay man and a lesbian woman, rather than a gay man and a straight woman. ${ }^{168}$ By pointing out that both a gay man and a lesbian woman would be treated the same by an employer discriminating based on sexual orientation, the employer cannot be discriminating "because of . . . sex" under Title VII. ${ }^{169}$ This argument was also made regarding interracial marriage - that a white man married to a black woman and a black man married to a white woman were discriminated against equally. ${ }^{170}$ Such arguments were disposed of in Loving v. Virginia, which directly stated that such arguments were "a limited view of the Equal Protection Clause which has not withstood analysis in the subsequent decisions of this Court."171 Similarly, the Court should dispose of such arguments with regard to discrimination based on sexual orientation, as the Seventh Circuit did in Hively. ${ }^{172}$

2. The Sex-Stereotyping Theory

Further, the Supreme Court has interpreted Title VII to protect

166. Baldwin, 2015 WL 4397641, at *5-6.

167. See Christiansen v. Omnicom Grp., Inc., 852 F.3d 195, 202-04 (2d Cir. 2017) (Katzmann, J., concurring), abrogated by Zarda v. Altitude Express, Inc., 883 F.3d 100 (2d Cir. 2018) (en banc).

168. See Hively, 853 F.3d at 366-67 (Sykes, J., dissenting).

169. See id. at 367-69.

170. Loving v. Virginia, 388 U.S. 1, 8 (1967).

171. Id. at 10 (quoting McLaughlin v. Florida, 379 U.S. 184, 188 (1964)).

172. Hively, 853 F.3d at 348-49. 
against discrimination based on failure to conform to sex stereotypes. ${ }^{173}$ As mentioned above, Price Waterhouse found that "[i]n forbidding employers to discriminate against individuals because of their sex, Congress intended to strike at the entire spectrum of disparate treatment of men and women resulting from sex stereotypes."174 This undoubtedly includes discrimination based on sexual orientation. The idea that men should marry women and women should marry men is perhaps one of the most prevalent gender stereotypes in the United States today. ${ }^{175}$ The EEOC addressed this in Baldwin, where it stated that

[S]tereotypes about homosexuality are directly related to our stereotypes about the proper roles of men and women .... The harasser may discriminate against an openly gay co-worker, or a co-worker that he perceives to be gay, whether effeminate or not, because he thinks, 'real' men should date women, and not other men. ${ }^{176}$

Courts that have held Title VII does not protect against discrimination based on sexual orientation ignore this truth and struggle to apply the Price Waterhouse holding. ${ }^{177}$

Turning back to the Eleventh and Second Circuit opinions in Evans and Omnicom, where courts attempt to separate sexual orientation from sex-based stereotypes, the analysis is confusing and awkward. In Omnicom, for example, the court noted that "the district court's decision draws attention to some confusion in our Circuit about the relationship between gender stereotyping and sexual orientation discrimination claims," 178 and that:

In its decision, the district court described at length difficulties in distinguishing sexual orientation discrimination claims from gender stereotyping claims, specifically noting that negative views people hold of those with certain sexual orientations mav be based on stereotypes about appropriate romantic associations between men and women.

173. Price Waterhouse v. Hopkins, 490 U.S. 228, 250-52 (1989).

174. Id. at 251 (quoting City of L.A., Dep't of Water \& Power v. Manhart, 435 U.S. 702, 707 n.13 (1978)).

175. Hively, 853 F.3d at 346 (noting that modern American society views heterosexuality as the norm and homosexuality as the exception).

176. Baldwin v. Foxx, No. 0120133080, 2015 WL 4397641, at *8 (EEOC July 15, 2015) (quoting Centola v. Potter, 183 F. Supp. 2d 403, 410 (D. Mass. 2002)).

177. See, e.g., Christiansen v. Omnicom Grp., Inc., 852 F.3d 195, 199 (2d Cir. 2017) (per curiam), abrogated by Zarda v. Altitude Express, Inc., 883 F.3d 100 (2d Cir. 2018) (en banc).

178. Id. at 200 .

179. Id. (citing Christiansen v. Omnicom Grp., Inc., 167 F. Supp. 3d 598, 619-20 (S.D.N.Y. 2016)). 
Thus, courts recognize that it is difficult and unsatisfying to attempt to interpret Title VII along with Price Waterhouse in a way that leaves discrimination based on sexual orientation out of Title VII's scope. ${ }^{180}$ Luckily, however, there is a rational alternative: to accept the logical conclusion of the combination of Title VII's text and Price Waterhouse's guidance-like the EEOC in Baldwin and the Seventh Circuit in Hively - and determine that discrimination based on sexual orientation is discrimination based on sex-based stereotypes and therefore prohibited by the Act.

\section{The Associational Theory}

Title VII's prohibition of sex discrimination also includes the prohibition of discrimination based on sexual orientation because discriminating on the basis of sexual orientation is "associational discrimination on the basis of sex." "181 Title VII "on its face treats each of the enumerated categories exactly the same." 182 That is, whether an employer discriminates based on race, color, religion, sex or national origin, the analysis by the court should be the same, and the principles held by the Supreme Court about one of the categories apply to the other categories. ${ }^{183}$ Thus, in determining how to interpret "sex" as used in Title VII, one must also consider how the Court has interpreted other enumerated categories.

Here, courts have repeatedly found that "the statute prohibits discrimination based on an employee's association with a person of another race, such as an interracial marriage or friendship." ${ }^{184}$ This theory of interpreting discrimination based on race began with Loving $v$. Virginia, which found a ban on interracial marriage to be unconstitutional. ${ }^{185}$ Federal courts have since found the same to apply when interpreting Title VII. ${ }^{186}$ For example, the Eleventh Circuit in Parr v. Woodmen of the World Life Insurance Co. found that when "a plaintiff claims discrimination based upon an interracial marriage or association,

\footnotetext{
180. Id.; see also id. at 205-06 (Katzmann, J., concurring).

181. Baldwin, 2015 WL 4397641 , at *6.

182. Price Waterhouse v. Hopkins, 490 U.S. 228, 243 n.9 (1989).

183. See id. ("By the same token, our specific references to gender throughout this opinion, and the principles we announce, apply with equal force to discrimination based on race, religion, or national origin.").

184. Baldwin, 2015 WL 4397641, at *6 (citing various EEOC and circuit opinions).

185. Hively v. Ivy Tech Cmty. Coll. of Ind., 853 F.3d 339, 347 (7th Cir. 2017) (en banc) (citing Loving v. Virginia, 388 U.S. 1, 12 (1967)).

186. Hively, 853 F.3d at 347-48 (discussing various cases).
} 
he alleges, by definition, that he has been discriminated against because of his race." 187 The Second Circuit agreed with this analysis in Holcomb v. Iona College where it found that discrimination against an employee because of his interracial association was "because of the employee's own race." 188

This analysis applies equally to discrimination against those individuals who have entered into same sex relationships. ${ }^{189}$ Title VII prohibits employers from "treating an employee or applicant differently than other employees or applicants based on the fact that such individuals are in a same-sex marriage or because the employee has a personal association with someone of a particular sex."190 Thus, the employer who fires a woman for being married to a woman discriminates against the employee because of her own sex, just as the employer who fires a white man for marrying a black woman discriminates against him because of his race. ${ }^{191}$ Therefore the Supreme Court should apply the Associational Theory to find that the employer who discriminates based on sexual orientation engages in "associational discrimination on the basis of sex."

\section{Interpreting Title VII in Line with the Original Purpose}

Even if the Court were to decide that the statutory construction of Title VII laid out above was not clear enough, the intent of Title VII also leads to the conclusion that the Act prohibits discrimination based on sexual orientation. The question of congressional intent is not so narrow as to only include exactly what was in the minds of members of Congress when they passed the statute in question. ${ }^{193}$ Considering the purpose of Title VII in 1964, it still seems that a prohibition of

\footnotetext{
187. 791 F.2d 888, 892 (11th Cir. 1986) (emphasis in original).

188. 521 F.3d 130, 139 (2d Cir. 2008) (emphasis in original).

189. See Price Waterhouse v. Hopkins, 490 U.S. 228, 243 n.9 (1989) (Title VII covers all protected classes equally); Hively, 853 F.3d at 349 (noting that it is immaterial to the court's analysis that Loving addressed racial discrimination); Baldwin, 2015 WL 4397641, at*7 (stating that Title VII's protections apply the same to gender as they do to race).

190. Baldwin, 2015 WL 4397641, at *7.

191. See Parr, 791 F.2d at 892; Holcomb, 521 F.3d at 139.

192. Baldwin, 2015 WL 4397641 , at $* 6$.

193. Frankfurter, supra note 157, at 539 ("[Statutory purpose] is what the judge must seek and effectuate, and he ought not to be led off the trail by tests that have overtones of subjective design. We are not concerned with anything subjective. We do not delve into the mind [sic] of legislators or their draftsmen, or committee members."); see also Hively, 853 F.3d at 350 n.5 (2017) ("[W]e are concerned with the provisions of the law, not the principal concerns of those who wrote it." (citing Oncale v. Sundowner Offshore Servs., Inc., 523 U.S. 75, 80 (1998))).
} 
discrimination based on sexual orientation would be included in that goal. In fact, when the Civil Rights Act of 1964 was signed by President Lyndon B. Johnson, he stated that "the purpose of the law is simple. . . [T] he only limit to a man's hope for happiness... shall be his own ability." "194 Of course this is limited to those categories listed in the statute - race, color, religion, sex, and national origin; ${ }^{195}$ however, the stated purpose remains broad.

Further, as mentioned above, although Congress added the sex amendment of Title VII later, and therefore less legislative history exists to consider, the ultimate point of adding the amendment was to make coverage of the Act as comprehensive as possible. ${ }^{196}$ Both the stated purpose, as well as that which can be discovered from the history of the sex amendment, point to an act that provides comprehensive coverage within the enumerated categories, and the courts should seek to provide this in their analyses.

However, the Court is not limited to the specific purpose in the heads of legislators at the time that Title VII passed in deciphering the purpose of the statute. Rather,

[T] he purpose which a court must effectuate is not that which Congress should have enacted, or would have. It is that which it did enact, however inaptly, because it may fairly be said to be imbedded in the statute, even if a specific manifestation was not thought of, as is often the very reason for casting a statute in very general terms. ${ }^{19}$

The Hively court makes a similar argument addressing the dissent's position that Congress, acting in 1964, could not have intended to protect against discrimination based on sexual orientation, stating that "[a]s Oncale said, we are concerned with the provisions of the law, not the principal concerns of those who wrote it." ${ }^{198}$ Oncale also stated that "statutory prohibitions often go beyond the principal evil to cover reasonably comparable evils." 199 The Supreme Court has consistently held this position with regard to Title VII, choosing on many occasions

194. Bayer, supra note 144, at 402 (quoting President Lyndon B. Johnson, Radio \& Television Remarks upon Signing the Civil Rights Bill, 2 PUB. PAPERS 842, 843 (July 2, 1964) (transcript available at https://millercenter.org/the-presidency/presidential-speeches/july-2-1964-remarks-uponsigning-civil-rights-bill [https://perma.cc/P4FF-TNZU]).

195. 42 U.S.C. $\S 2000 \mathrm{e}-2$ (a) (2012).

196. Case, supra note 20, at 1340.

197. Frankfurter, supra note 157, at 539.

198. Hively, 853 F.3d at 350 n.5 (citing Oncale, 523 U.S. at 80).

199. Oncale, 523 U.S. at 79. 
to apply it in ways that the Congress in 1964 may not have intended. ${ }^{200}$ Here, discrimination because of sexual orientation is at the very least a reasonably comparable evil to that of discrimination because of sex. Thus, considering both the intent of Title VII to provide comprehensive protection and the provision's reasonable applicability to sexual orientation discrimination, the Supreme Court should find that Title VII prohibits discrimination because of sexual orientation.

\section{Public Policy Favors Inclusion}

The Seventh Circuit's interpretation is also beneficial from a policy point of view for two reasons. First, determining the meaning of sex discrimination under Title VII would clarify an area of law currently in flux in a manner consistent with our nation's changing values and, second, ensure that LGBTQ individuals in all parts of the nation are afforded the same protection under the law.

First, determining that the Title VII prohibition of discrimination on the basis of sex includes sexual orientation discrimination would make Title VII application uniform throughout the nation and will bring Title VII law into conformity with other areas of law that protect gay, lesbian and bisexual individuals. Citizens in all jurisdictions should be able to enjoy the protections of federal law equally regardless of their location.

Further, an interpretation by the Supreme Court that finds Title VII prohibits sexual orientation discrimination would also bring the application of Title VII into conformity with other areas of law regarding LGBTQ individuals in the United States. Consider, for example, Romer v. Evans, which found that "a provision of the Colorado Constitution forbidding any organ of government in the state from taking action designed to protect 'homosexual, lesbian, or bisexual' persons violated the federal Equal Protection Clause." ${ }^{201}$ Or, consider Lawrence v. Texas, where the Court invalidated a Texas statute making same-sex intimacy criminal. ${ }^{202}$ Additionally, United States v. Windsor found the Defense of Marriage Act's definition of "spouse," which did not recognize same sex partners, unconstitutional, and, of course, Obergefell v. Hodges found that "the right to marry is a fundamental liberty right, protected by the Due Process and Equal Protection Clauses of the Fourteenth

\footnotetext{
200. See supra note 34 and accompanying text.

201. Hively, 853 F.3d at 349 (citations omitted) (citing Romer v. Evans, 517 U.S. 620, 624 (1996)).

202. Lawrence v. Texas, 539 U.S. 558 (2003).
} 
Amendment." ${ }^{203}$ While these cases speak to the violation of constitutional provisions and not the application of Title VII, they show a fundamental view that gay, lesbian, and bisexual Americans are entitled to the same protection as their straight counterparts. Thus, the Supreme Court should end this inconsistency and find that under Title VII, lesbian, gay, and bisexual Americans are entitled to protection under Title VII's prohibition of sex discrimination.

\section{CONCLUSION}

The Supreme Court will eventually face the decision of whether Title VII's prohibition on discrimination "because of ... sex" includes discrimination based on sexual orientation. When that time comes, the Court should find that it does. The background explored in this comment shows that not only has the history of the prohibition of sex discrimination in Title VII history been misunderstood and used to unduly restrict Title VII application, but also that the Supreme Court has been interpreting Title VII to apply broadly for a number of years. ${ }^{204}$ Furthermore, this Comment has noted the modern arguments for and against protection under Title VII against sexual orientation discrimination. The analysis then addressed the issue of precedent and argued that the Federal Circuit Courts could and should be willing to, when possible, overrule precedent that often fails to engage in the meaningful analysis required after Oncale and Price Waterhouse.

Even if the circuit courts do not change their stance on the issue of Title VII protection against discrimination based on sexual orientation, the Supreme Court should. The Court should consider that the plain meaning and original purpose of Title VII, combined with Price Waterhouse and Loving precedents relating to sex-stereotyping and associational discrimination lead to the conclusion that Title VII prohibits sexual orientation discrimination.

There are also important policy reasons to decide the issue at hand as laid out above. A prohibition of sexual orientation discrimination would afford all Americans the same protection under the law regardless of their sexual orientation or their location. ${ }^{205}$ A diverse workplace is a productive and effective workplace. LGBTQ individuals make important contributions to American businesses and employers should

\footnotetext{
203. Id. at 349-50 (first citing United States v. Windsor, 570 U.S. 744, 769-70 (2013); then citing Obergefell v. Hodges, 135 S. Ct. 2548, 2604 (2015)).

204. See supra Part III.

205. Supra Section IV.B.5
} 
not exclude them from the workplace purely because of their sexuality. It is time that the Supreme Court recognize that Title VII's prohibition on sex discrimination includes a prohibition on discrimination based on sexual orientation. 